\title{
古脊椎动物化石的新成就
}

\author{
楊鍾健
}

（中国科学院古脊椎动物研究所）

1959 年, 古春椎动物学也和其他战䋐上一样, 在 1958年大跃进的基础上継續大跃进，取得了巨大的成 10

中苏古生物考察队在中国科学院和苏联科学院的 正确領导和支持下，于1959年 6 月开始出发，首先在 內蒙二連地区从事工作, 以后在以东的通古尔盆地、伊 尔丁曼哈、烏拉烏苏等过去美国人所考察过的地点进 行勘查和发掘, 殿后又在河套地区和內蒙西部进行了 远距离的路綫調查。在許多地点发現了大批化石。此 外，在西部还发現了两个化石十分丰富的地点。

配合全国地层会議，1959年 7 月，在山西石开了 一个山西地层現場会議。这次会議大大地推动了該地 区关于三迭紀中国肯氏兽动物莘的发現, 使我們有更 进一步的了解。特別是在宁武、静乐等地发現了更多 的新化石地点和化石。另外在其他地点,如山西兴县、 保德、沈县等地也找到了可以鑑定的中国肯氏兽动物 的化石或骨䯓的遗迹, 这些发現对于了解这个地稹 时期的地层的发有和分布也具有头等重姴意义。

周口店中国猿人地点的发掘工作在 1959 年也有 知出的成就，得到了一个相当完整的下顎骨，其他哺 和动物化石也有㙁加。1959 年 12 月召开了中国猿人 第一个头盖骨发現 30 周年紀念会，在会上宣讀了将 近 30 篇的学术报告，从这些报告中可以看出，除了 中国猿人新的下領骨外，在其他方面也都有显著的进 展, 如广西巨猿材料的坦加, 旧石器的大量发現等 事。

中国科学院古脊椎动物研究所的工作队发見了一 些重要化石，各生产队、各文新門、歌多博物館和 一般人民来信，也提供了大量的新材料，其中一部尔 具有非常而要的地层学或生物学意义，或两者軹而有 之。以下只就一般脊椎动物化石的重要发見与研究加 以扼要敘麻。

\section{魚 类}

关于魚类化石 1959 年作出了相当突出的成績, 从 老到新計为;

在貴州兴义产貴州幻龙的中三迭紀地层，发現了 一些魚化石,这些魚化石由苏德造呼究計共有三种,都 归硬鳞魚类，分为亚全骨目和全骨目两目，都是新种， 包括两新属。时代是中三迭紀。这是中国第一次游相 或海緣相魚类化石的发見和㸴究。使我們对中生代魚 类的知識迈进了一大步。

在陝西神木由西北地盾大队发見了保存很好的角 齿魚化石。經刘先亭、叶祥重研究定名为神木角苏魚。 以前角些魚只在四川云南的中生代地层有所发見，在 我国北方发現非常有意思。据作者意見，这种陝西的 角药魚和四川的角齿魚相近，因之可能加强四川䀀地 和傸北齐地的地层对比。另外，以前在傸北曾发䍐过 肺魚类化石，目前角齿魚的发見，一方面証实了以前 的看法，一方面也表明这一种魚可能还要大量发見。

在山西榆社上新統盆地中富有魚化石是早就知道 的事实。但是从未詳加研究。1959年古脊椎动物呼究 所把历年收集的大量标本由刘先亭、苏德造加以研究。 結果証明这是一个十分丰䈏的鮭动物翌。它包括了十 三种魚，分属三个目，就是鯉形目，为这一魚动物堅 的主要組成者, 共归两科, 十属, 十一种。另两目是 鯱形目和能形目各一科，一属，一种。这一个动物翠 是一个典型的湖相魚翠, 多为現代种, 只有五个种是 新的。榆社系魚类化石的研究代表着迄今为止我們在: 中国所知道的最丰富的动物龺，从而丰富了我們对于. 新坐代后期魚化石的知識。

魚化石的研究一向赶不上实际需要，尽管近年来 做了一些工作，但待研究的材料还是很多，最近在从 未发現过魚化石的江西、河南等省，也发現了魚化石。 
另外在全国各地及新增了二十多个魚化石产地。

\section{两 栖 类}

中国的两栖类化石一直知道的很少，是一个空白， 前在山西武乡曾发見了迷齿类的骨板，已有报导。1959 年山西地层現場会議时曾在宁武石盒子系发見了可能 是迷奖类的一个牙岁。关于这方面的工作，还有待推 进。

特別有意义的是在㮬藏系中，曾发見了一个保存 非常完好的蛙化石。这个标本是一个完整的蛙，已由 刘玉海研究，定为榆社蛙，这是在我国第二次发見的 完整的蛙化石。第一次是在上中新統的山旺系。榆社 蛙在生物演化和地层意义上虽不如其他化石的重要， 但标本保存完善，同时也說明当时沉积时的环境。

\section{爬 行 类}

1959年，爬行动物化石方面也有很大进展。由于 为山西地层現場会議做准备工作，在山西宁武县二馬 营附近找到保存更好的肯氏臱动物慗，抹且在附近勘 測了詳細剖面，为煘定二馬营組的基础。这地方的肯

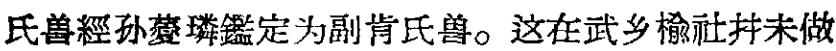
大量采集工作，但对已采的化石在砫究工作上頗有进 展。由叶祥奎碑究了肯氏兽以外的二茵兽类，其中有 一新属, 定名为山西兽。这个山西兽具有肯氏兽若千 性稹，但还有是多的二齿兽科的性稹，极为有趣。另 外，也从中国肯氏兽中分出了副肯氏兽一属，是由孙 督璘做的。其他化石方面，記述了中国犬顎兽和山西 既。这末一来，武乡榆社的中国肯氏兽动物㢣內容更 有了明确的了解。

中国肯氏兽动物帮看来分布十分广泛，宁武附近 的静乐、兴县均有其迹，在山西保德乃至陝西府谷等 地均有其分布。特別有兴趣的是最近在山西保德林遮 峪发見了前稜蝴一类的残先,其种虽然和武乡的不同， 但这一类动物的广泛存在是无疑問的，可能正策中国 肯氏兽一样，前稜虲也不止一个层位，如果保德的种 和武乡的不同的話。

上边談到在貴州发現的海緣相魚和奵龙化石，大 䄪可以和兴义幻龙相比，从在貴州仁怀发見的一些部 分骨骼初步制断，可能是幻龙一类的化石。此外，在 四川重庆大坪也发見了一个上臂骨，也很象三迭紀的 幻龙。这样看来，我国西南各省三迭紀幻龙的分布远 比我們想象的多而广，这是今后工作的一个新的方向， 也就使海相爬行动物化石，大有前途。
最近在东北吉林省輝南县杉松南发見了很大的足 印化石，虽然很大，但构造上却可和在辽宁西部发見 的热河足印不无相同之处，另外在山东䓪县也发見了 完整的鳞龙类化石。

\section{哺 乳 类}

1959 年, 在哺乳动物化石方面, 也有很大的成就, 首先是 1959 年中苏古生物考察队的工作,在哺乳动物 化石方面，成績非常突出。除了在二連发風的一些恐 龙等化石以外，其他工作可以說几乎全是哺乳动物方 面的收获，其中最重要的有:

1. 仅仅在內蒙烏拉烏苏一地就发見了古鹿 (Archaeomeryx)骨架就有三十多个，此外，还有年龄不同 的雷兽，构造特別的原始犀牛等。在其他一些地点（大 多数是美国人做过的一些地点）发見了更为丰富的第 三紀初期的化石。另外，在內蒙西南部发見了素海眖 地点，大約是下漸新統时代，化石十分丰富，还有待 1960 年发掘。

2. 在通古尔，上中新梳的化石也有新的收获。

3. 在內蒙华德县发見了含安琪馬的化石,和年代 稍新的 (上新統)哺乳动物萃。此外，在河套准噶尔旗 也发見了主要以三趾馬为代表的化石（另外也有一些 第三紀初期地点)。

除了中苏古生物考察队所取得的成就以外，在其 他地点也发見了一些重要的化石地点：

1. 在新疆吐魯番玢地发見了古恐角兽,相当于蒙 古加沙头地罢，这就代表了一个渲正的古新梳地晨， 是十分重要的。

2. 在貴州施秉县发見了石炭兽科化石,时代可能 为中新統或下上新統。在贵州从来没有发見过洞穴堆 积以外更老的哺乳动物化石，因而这一发見标志着在 貴州第一次发見的第三紀哺乳类化石地层。

3. 在河南西南的浙川永地以前就知道有第三紀 初期化石存在,不过近来发胃了新的哺乳动物化石，以 前的化石都是少而不完全。通过这次发見，相信可以 对那一地区的第三紀初期化石有更多的了解。

从以上簡要的敍述，可以知道在古春椎动物化石 方面，1959年取得了很大的成果。有的是对于过江的 材料經过研究，大大地提高了一步，有的标志着一个 新的研究方向的兴起，有的填补过去所不清楚的一个 地稹时代，有的扩大对于一个新的区域脊椎动物化石 的訪識。我們对于古春椎动物化石的知識和它对于实 际上的应用都大大提高了一步。 